\title{
CLEAR VISION FROM THE END OF THE EARTH
}

A pragmatic and deliberate approach to research funding yields impressive results, while New Zealand's geography makes it a perfect natural laboratory for Earth scientists, writes Linda Vergnani.

W hile seismologist Martin Reyners works in his office, he is quietly awed that 23 kilometres below him the Australian Plate is slowly colliding with the Pacific Plate, a process that could trigger an earthquake at any moment.

"It's a wonderful laboratory for studying tectonic processes," says the researcher, of his Lower Hutt workplace, near Wellington in New Zealand. "We can sit above a subduction zone, like we have on the North Island, with instruments on land and see what is happening between the plates. That is not possible in any other subduction zone almost anywhere else in the world, including Japan," says Reyners, who works for GNS Science, one of New Zealand's seven Crown Research Institutes.
In collaboration with New Zealand's Earthquake Commission, GNS Science runs the country's earthquake, volcano and geological hazard information network, GeoNet. They manage and monitor hundreds of seismographs across the country, using real-time data to relay hazard information to officials and, via the GeoNet website and app, keep the public updated. "My job is understanding what kinds of earthquakes we might expect and then alerting the authorities so they can plan and inform people about them, and design buildings to withstand them," says Reyners, a fellow of the Royal Society of New Zealand.

Even seismologists had not anticipated a series of earthquakes that shook the country's South Island during 2010 and 2011. The
Canterbury sequence, as it is known, included thousands of quakes ranging from magnitude 3 to 7.1. The most destructive, the magnitude 6.2 Christchurch aftershock, killed 185 people when it hit on 22 February, more than five months after the initial 7.1 magnitude Darfield earthquake that triggered the sequence. Reyners says the sequence caused damage worth between NZ $\$ 40$ to $\$ 50$ billion, equivalent to more than 15\% of the country's annual GDP.

Because the area was so well instrumented, the sequence was one of the best ever documented. Reyners' team showed that the Christchurch earthquake's destructive power — buildings were torn apart - was caused by the "very unusual, strong rock" under the city, which produced some of the most powerful 
vertical acceleration ever recorded for an earthquake that size. "That finding resulted in a Nature Geoscience paper," says Reyners.

The paper was among dozens published by GNS scientists on the geophysics, seismology, tectonics and other aspects of the sequence.

While New Zealand is small and isolated on the outer edge of the Pacific, many of its research strengths are rooted in the benefits and challenges of its unique geology and natural environment. In the Nature Index the country ranked 30th overall in 2015, just above Chile and Saudi Arabia, countries with much larger populations. In Earth and environmental sciences, New Zealand ranked 15th. The country's proximity to Antarctica has also led to a strong showing in climate science.

Richard Blaikie, deputy vice-chancellor of research and enterprise for the University of Otago, says that, despite its population of just 4.5 million people, New Zealand produces more scientific publications per dollar input than any other country. The University of Otago was the country's top-performing institution in the index last year, followed by the University of Auckland.

Blaikie describes one of the country's research advantages as the "Lord of the Rings effect". Just as its unique and diverse environments have been a boon for filmmakers such as Peter Jackson, "likewise, for the geological and environmental scientists it's a really, really interesting place to be." Geographically long and narrow, the country has many interesting geological features, a range of climates and unique biota. "We have the eighth largest marine exclusive economic zone in the world and our ocean waters are recognized as a hotspot for biodiversity," Blaikie says.

Like many countries, the New Zealand government encourages its scientists to pursue applied research that contributes to the economy, environment and society. Central to the government's National Statement of Science Investment 2015-2025 are research excellence and impact. "All of our science should have a strong line of sight to benefits for individuals, businesses or society," the statement reported.

But some critics maintain the government's policies are now weighted too heavily towards applied research, particularly since science funding was centralized in 2012 under a super Ministry of Business, Innovation and Employment. They claim the strong focus on practical outcomes has hampered independent, blue-sky research. Contributing to a special 2015 issue on the future of science in New Zealand in the Journal of the Royal Society of New Zealand, retired interdisciplinary scientist and futurologist John Robinson wrote this had "limited science to prescribed channels and blocked innovation".

\section{GOVERNMENT STRATEGY}

Blaikie, who is a professor of physics and still publishing research, says: "In the university sector, we are mandated through legislation to be a research-led institution."

The University of Otago's focus on research that has an impact is not just about commercialisation, he says. "It's about connecting to enterprise, be that a social, community, a health or economic enterprise," says Blaikie, adding that the university's research "aims to influence not just local but global policy."

For example, the university has had a strong research focus on tobacco control for more than two decades, which has had a major influence on informing Australia's world-first policy that cigarettes be sold in plain packaging. The university's current research involves public health and marketing researchers looking at interventions to help achieve the government's goal of making the population essentially smoke-free by 2025 .

\section{GLOBAL POLICY}

Cardiovascular research led by Mark Richards, director of the university's Christchurch Heart Institute (CHI), has had a profound impact on public health. In 1996 Richard's team identified a marker for diagnosing heart failure, a peptide known as NT-proBNP. They pioneered an intervention for heart failure that was guided by measuring the levels of NT-proBNP in the blood of patients. An international follow-up study of 35 centres that adopted the strategy found it resulted in 35\% fewer deaths in patients under 75 .

New Zealand's focus on research that benefits the economy or society was cemented in 1992 when the government established Crown Research Institutes, government owned businesses that conduct scientific research, but must also remain financially viable.

Ian Graham, general manager of research at one of these institutes, GNS Science, says: "We are kind of a strange, hybrid research institute. We operate as a company, we have a board, we have to return a financial performance in relation to return on equity and sometimes we pay a dividend to government." GNS acts as a consultancy and conducts research in resources, including geothermal power and petroleum exploration. It receives around a third of its

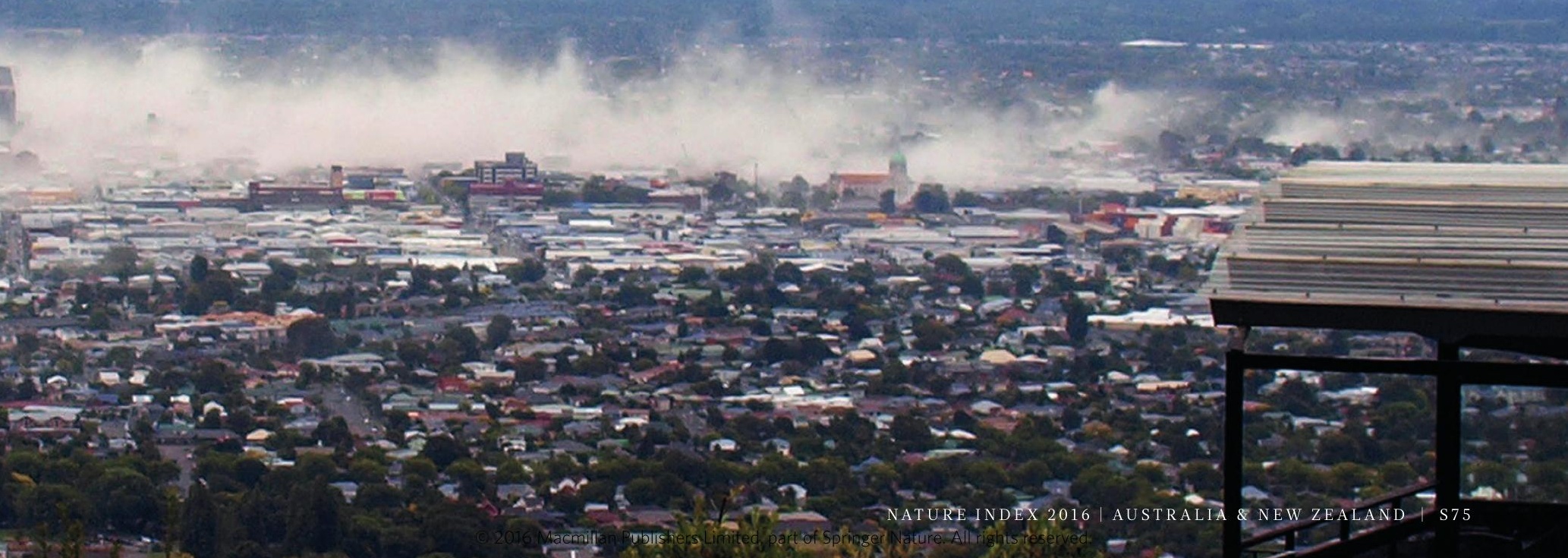



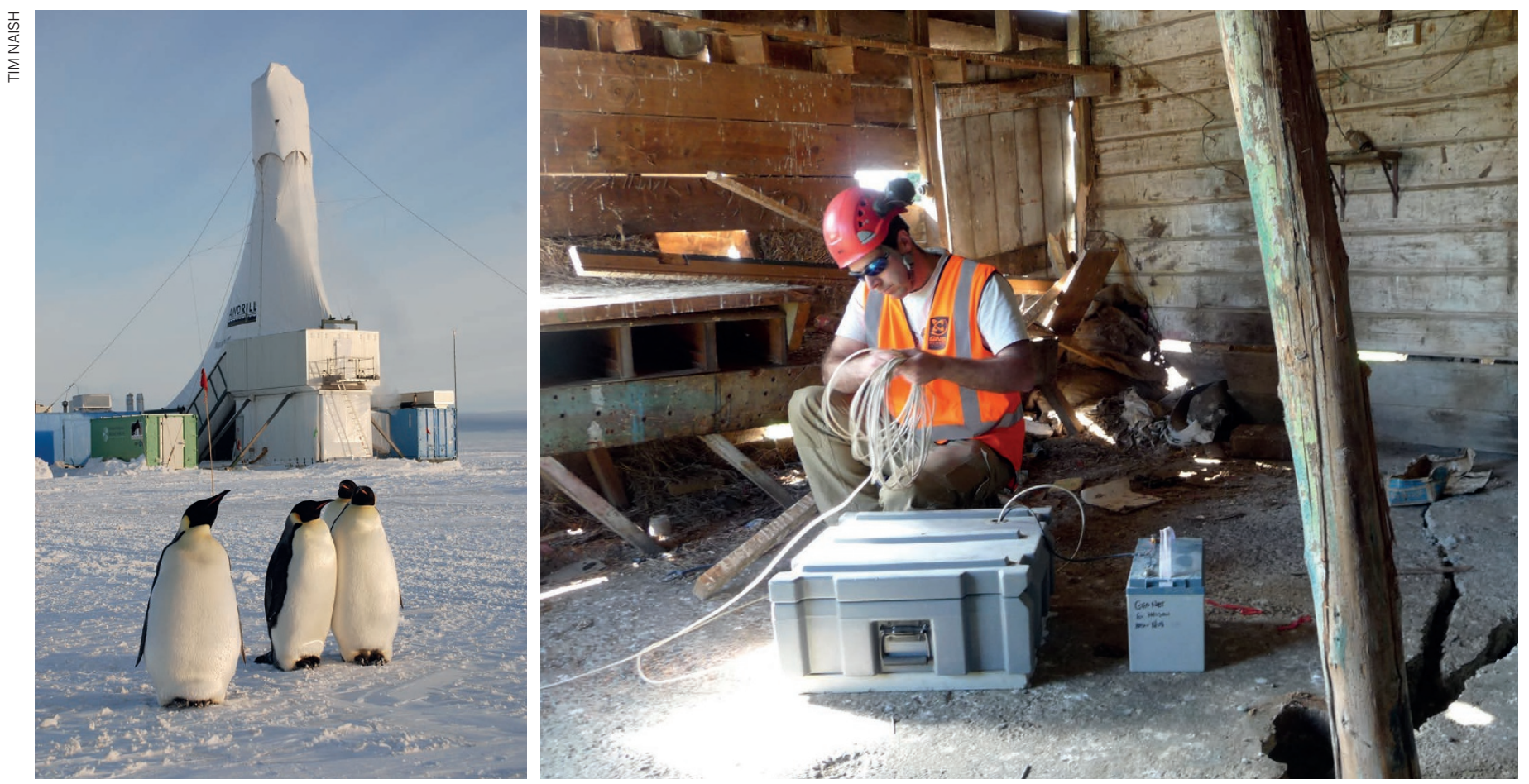

ANDRILL rig operating in McMurdo Sound, Antarctica. Andrew Cowie from GeoNet installing a seismograph in a damaged shed after an earthquake.

\section{CROWN INSTITUTES COLLABOBATE}

The share of domestic versus international collaborations of three Crown Research Institutes. Their contribution to the index over the past 12 months is shown as weighted fractional count (WFC).

KEY

Domestic

International

* data from July 2015 to June 2016

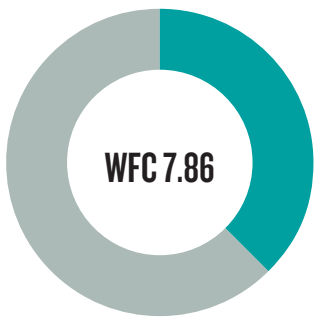

GNS Science

$37.75 \%$

$62.25 \%$

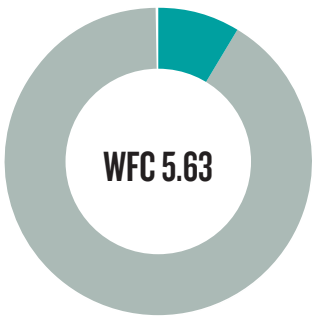

NIWA

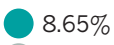

$91.36 \%$

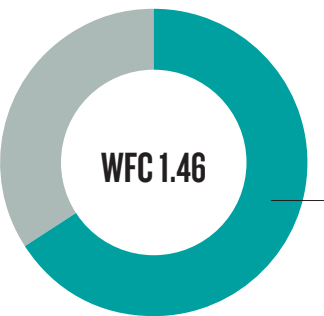

AgResearch

$65.89 \%$

$34.11 \%$
AgResearch's top international partners were Heinrich Heine University Dusseldorf in Germany and the University of Hong Kong. core funding from government and competes against universities for applied science and basic research funding from other sources.

Although Crown Research Institutes are run as businesses, their research must strive for excellence, and involve collaborations with other research organizations, both locally and internationally (see graphic). GNS has formed strong partnerships with universities in fields such as Antarctic science, tectonics and climate research. Three institutes feature in the top ten New Zealand institutions in the Nature Index in 2015: GNS Science, the National Institute of Water and Atmospheric Research (NIWA) and AgResearch. In fields such as Antarctic science, tectonics and climate research GNS has formed strong partnerships with universities. Research on the southern-most continent is another of New Zealand's strengths. Timothy Naish, director of the Antarctic Research Centre at Victoria University of Wellington and a former chair of the international ANDRILL (Antarctic Geological Drilling) Science Committee says "We have a big international reputation for Antarctic paleoclimate research." New Zealand operates Scott Base on Antarctica's Ross Island.

\section{PALEOCLIMATE RESEARCH}

Naish's group is helping answer the big question of how the Antarctic ice sheet will contribute to global sea level rise under different global warming scenarios. Victoria University of Wellington, which ranked third in New Zealand in the index last year, has a 60-year tradition of geological investigations in Antarctica, developing unique drilling technology to extract geological records and ice cores, he says. "Other countries say to us, we want to work with you."

Naish's team works closely with colleagues in Germany, the United States, the United Kingdom, Australia and Italy and is also developing strong relationships in Japan and Korea. This year, Naish was part of a team, led by GNS' Richard Levy, that discovered just how sensitive ice sheets are to changes in carbon dioxide. The paper was published in the Proceedings of the National Academy of Sciences. Because climate change is a global issue, Naish says the research generated by his centre has become more policy relevant in the last 10 years.

But Naish says there is a lack of targeted funding from the government for future Antarctic research. "This will definitely affect our ability to make long-term strategic decisions, including participating in international collaborations," he says. While there was a boost in the last budget for supporting Antarctic operations and infrastructure, such as renovations of Scott Base, there was no long-term "planning security" for Antarctic researchers. "We find it really frustrating that we have this high quality of research, but we can't get the government excited about it," Naish says. 